\title{
Species Composition and Abundance of Zooplankton in the Nearshore Beaufort Sea in Winter-Spring
}

\author{
RITA HORNER ${ }^{1}$ and DAVID MURPHY ${ }^{2}$
}

\begin{abstract}
Zooplankton samples collected in winter-spring 1978-79 and in spring 1980 from under the sea ice at two sites near Prudhoe Bay, Alaska, were analyzed for species composition and abundance. Sixty-eight categories, including 48 species and 20 other categories where identification was made to genus or other higher taxonomic rank, were identified.

Calanoid copepods were dominant under the ice. As spring progressed, however, other organisms, including cyclopoid and harpacticoid copepods, hydrozoans, amphipods, larvaceans, and larval stages of planktonic and benthic invertebrates, became more numerous. Some of these organisms, such as cyclopoid and harpacticoid copepods, probably lived in the sea ice in early spring and were released into the water column as the ice melted.

A correlation matrix identified three groups of zooplankton. Group one, consisting of Pseudocalanus spp., had large fluctuations in numbers throughout the spring. Group two, consisting of benthic copepods, polychaetes, and the amphipod Halirages mixtus, became abundant when the ice began to melt. The third group, composed of all other species, had a more uniform abundance during early spring, but declined in numbers as the ice melted.
\end{abstract}

Key words: western Beaufort Sea, zooplankton, copepods, Pseudocalanus, cyclopoids, harpacticoids, sea ice

\begin{abstract}
RÉSUMÉ. Des échantillons de zooplancton recueillis sous la glace marine près de la baie Prudhoe, en Alaska, au cours de l'hiver de 1978 et du printemps de 1979 furent analysés afin d'en déterminer les espèces et leur nombre. Soixante-huit catégories furent relevées, y compris 48 espèces et 20 autres catégories identifiées par genre ou par rang taxonomique supérieur.

Les copépods Calanus figuraient en nombre supérieur sous la glace. Cependant, à mesure que le printemps avançait, d'autres organismes augmentaient en nombre, y compris des copépodes cyclopes et harpacticoides, des hydrozoaires, des amphipodes, des appendiculaires, et des invertébrés planctoniques et benthiques aux stades larvaires. Certains de ces organismes, tels les copépodes harpacticoides et cyclopes, vivent probablement dans la glace marine au début du printemps et sont libérés dans la colonne d'eau avec la fonte de la glace.

Une matrice de corrélation signale trois groupes de zooplancton. Le premier consiste de Pseudocalanus spp. et présente d'importantes fluctuations en nombre durant la saison entière. Le deuxième groupe consiste de copépodes benthiques, de polychètes et d'amphipodes Halirages mixtus et devint abondant avec la fonte. Le troisième groupe, composé de toutes les autres espèces, figurait en nombre abondant uniforme tôt durant le printemps, mais diminua en nombre avec la fonte.
\end{abstract}

Mots clés: ouest de la mer de Beaufort, zooplancton, copépodes, Pseudocalanus, cyclopes, harpaticoides, glace marine

Traduit pour le journal par Maurice Guibord.

\section{INTRODUCTION}

The earliest collections of zooplankton from the nearshore region of the arctic coast of Alaska were made during the International Polar Expedition to Point Barrow (Murdoch, 1885) and during the Canadian Arctic Expedition of 1913-18 (Bigelow, 1920; Shoemaker, 1920; Willey, 1920; Schmitt, 1919). These studies consist primarily of distribution records and taxonomic descriptions.

More recently at Point Barrow, MacGinitie (1955) briefly discussed zooplankton in terms of relative abundances and reproductive periods, while Johnson (1958) described the qualitative and quantitative composition of the inshore zooplankton community for one month during summer. Redburn (1973) described the zooplankton community in terms of species abundance and composition, life cycles, and relationship to the hydrographic regime.

Following the discovery of oil on Alaska's North Slope in 1968 , a number of studies were initiated to provide basic background information about the nearshore ecosystem, but most of the invertebrate studies have been confined to benthic and epibenthic species (Crane and Cooney, 1974; Broad, 1978; Broad et al., 1979; Griffiths and Dillinger, 1981) or to zooplankton collections made farther offshore (English and Horner, 1976, 1977; Horner, 1978, 1979, 1981).

At Prudhoe Bay in August, however, Horner et al. (1974) found three areas biologically differentiated from one another based on zooplankton community structure and the relative abundance of species comprising the community. Inside Prudhoe Bay, the copepod Acartia clausi was the dominant species, with Pseudocalanus sp. also being numerous. Between Prudhoe Bay and the Midway Islands, Calanus glacialis and Pseudocalanus sp. were the dominant species. Oithona similis was present along with some barnacle larvae and crab zoea. A more diverse community occurred in the more oceanic area outside the barrier islands where Microcalanus pygmaeus, Pseudocalanus sp., and Chiridius obtusifrons were dominant. Meroplanktonic larvae of decapods, polychaetes, and barnacles were also present, along with juvenile shrimp and euphausids.

This paper describes seasonal changes in species composition and abundance of zooplankton in Stefansson Sound and off Narwhal Island during winter and spring.

\section{METHODS}

Zooplankton was collected from under the annual sea ice in November 1978 and March and May 1979 in Stefansson Sound and from April to June 1980 in the Beaufort Sea off Narwhal Island (Fig. 1).

Samples were collected in November 1978 and April-June 1980 with a $0.75 \mathrm{~m}$ diameter ring net having a mesh size of $308 \mu \mathrm{m}$. In March and May 1979, the $0.50 \mathrm{~m}$ diameter ring net had a mesh size of $209 \mu \mathrm{m}$. Vertical hauls in Stefansson Sound 


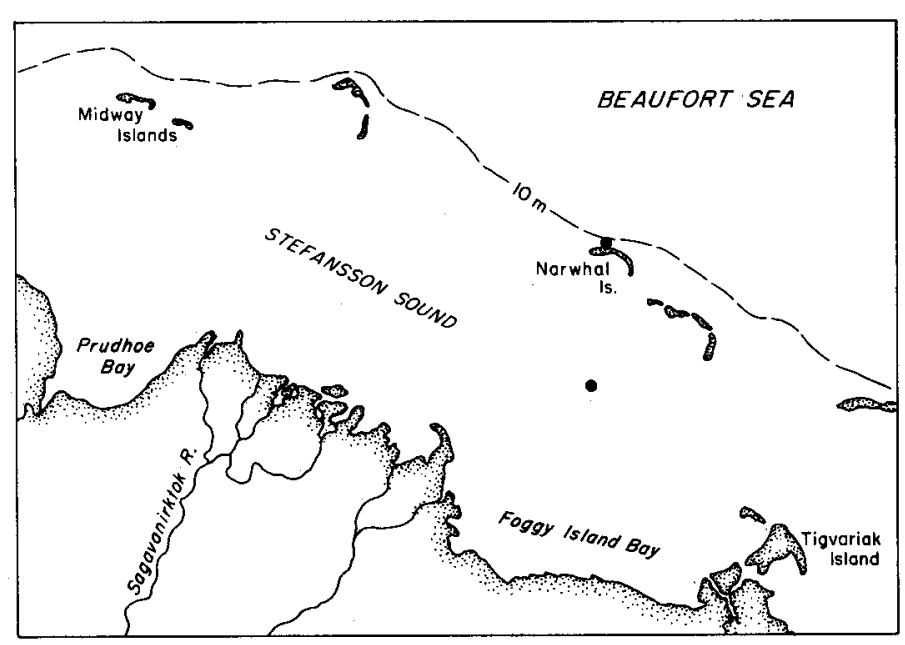

FIC. 1. Station locations.

were made by lowering the net to the bottom $(5 \mathrm{~m}$ depth) and retrieving by hand at a constant rate. Horizontal tows in Stefansson Sound (November 1978) and off Narwhal Island were made by attaching the net ring to a line and pulley system anchored to a post placed through the ice 12 or $14 \mathrm{~m}$ from the sampling hole. The net was lowered through the sampling hole and hand hauled horizontally as quickly as possible to the pulley and back, fishing at an average depth of $2 \mathrm{~m}$ beneath the ice. Tows were timed to obtain an approximate speed of tow of $0.3 \mathrm{~m} \mathrm{~s}^{-1}$.

The net was washed by dipping it several times in the sampling hole. The sample cup was removed and warmed slowly when ice was present. Samples were preserved in $4 \%$ formaldehyde buffered with sodium acetate.

All zooplankton samples were first sorted for large, rare organisms such as mysids, amphipods, euphausids, shrimp, and fish eggs and larvae. The samples were then split in a Folsom plankton splitter (McEwen et al., 1954) until a subsample containing ca. 100 specimens of the most abundant taxon was obtained. Subsamples were successively sorted until at least 100 specimens of abundant taxa or all specimens of rare taxa were counted and identified.

For copepods, samples that had previously been sorted for larger animals were subsampled with a calibrated automatic pipet to obtain a subsample containing ca. 100 specimens of the most abundant copepod species. Copepods were identified and counted by sex and copepodid stage.

The number of animals $\cdot 1000 \mathrm{~m}^{-3}$ was calculated using the equations:

$$
\begin{aligned}
& V\left(m^{3}\right)=\text { haul length }(m) \times \text { mouth area }\left(\mathrm{m}^{2}\right) \\
& \text { Number }\left(1000 \mathrm{~m}^{3}\right)=\frac{(A)(1000)}{V} \times 2^{\mathrm{n}}
\end{aligned}
$$

where $\mathrm{V}=$ volume of water filtered; $\mathrm{A}=$ number of animals counted; and $\mathrm{n}=$ number of times the sample was split.

A $35 \times 35$ member correlation matrix was constructed for the more common species collected in 24 net tows off Narwhal Island between April and June 1980. The Statistical Analysis System's (SAS Institute Inc., 1982) correlation procedure was used to generate Pearson coefficients for correlating the variation in abundance (number $1000 \mathrm{~m}^{-3}$ ) over time of a species with each of the other common species collected.

In addition to the zooplankton, primary productivity, chlorophyll $a$, microalgal species and cell numbers were determined at two depths in the water column and for the bottom few centimetres of sea ice at both the Stefansson Sound and Narwhal Island sites (Horner and Schrader, 1982).

\section{RESULTS}

\section{Description of the sampling sites}

Stefansson Sound is a shallow water sound off the Alaska North Slope extending from the Midway Islands to Tigvariak Island. It is bounded on the north by a series of barrier islands, including Narwhal Island, and on the south by the Alaskan coast (Fig. 1). Because of the protecting barrier islands, currents in the sound are weak, especially when ice is present. In the spring, salinity was near $18 \%$ at the water surface and $35 \%$ on the bottom at $5 \mathrm{~m}$. Ice is present from about midOctober until late June or early July, with maximum thickness, near $2 \mathrm{~m}$, occurring in early May.

The Narwhal Island site was located on a large flat pan of ice ca. $0.4 \mathrm{~km}$ north of Narwhal Island $\left(70^{\circ} 24^{\prime} \mathrm{N}, 147^{\circ} 31.1^{\prime} \mathrm{W}\right)$. Spring currents in the area are northward at ca. $2.5 \mathrm{~cm} \mathrm{~s}^{-1}$ (J.B. Matthews, pers. comm.). Salinity ranged from a low of $24.1 \%$ at the surface in early June to $35.7 \%$ on the bottom at $7 \mathrm{~m}$ depth in April-May. Only when the ice began to melt in early June was the salinity $<32 \%$ at the surface. Maximum ice thickness during this study was ca. $1.8 \mathrm{~m}$.

\section{Species composition and distribution through time}

Sixty-eight categories, including 48 species and 20 other categories where identification was made to genus or other higher taxonomic rank, were identified in the samples. Relative distribution of abundance through time is given in Tables 1 and 2.

Copepods, with 24 species present, were by far the most abundant group during the winter-spring period, ranging from 28-99\% of the total population at Narwhal Island and 99-100\% of the population in Stefansson Sound. Calanoid copepods were the most diverse group, with 12 species, during the whole period. Cyclopoids, with 7 species, and harpacticoids, with 4 species, became more abundant in late spring. Most of the copepods in our winter samples were adults, with juveniles generally appearing in spring.

In Stefansson Sound, Pseudocalanus spp. constituted $97 \%$ of the total population in November, $81 \%$ in March, but only $22 \%$ in May. Adults were the most abundant stages except in March, when stages I-III were more numerous. Other calanoid copepods present in Stefansson Sound were Derjuginia tolli, which was relatively abundant in November, and Acartia longiremis, Calanus glacialis, C. hyperboreus, Microcalanus pygmaeus, Eurytemora richingsi, Metridia lucens, and Limnocalanus macrurus, all present in relatively low numbers throughout the winter-spring period (Table 1). 
TABLE 1. Mean abundance (individuals $1000 \mathrm{~m}^{-3}$ ) of zooplankton in Stefansson Sound, November 1978, March and May 1979; November tows were horizontal, March and May tows vertical

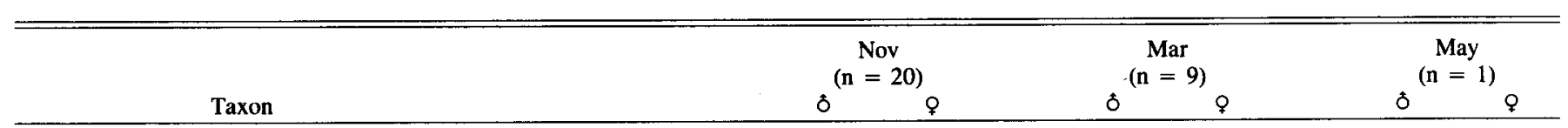

Cnidaria

Hydrozoa

Halitholus cirratus

Ctenophora

Pleurobrachia pileus

Polychaeta

Unidentified larvae

23

23

102

Crustacea

Cladocera

Eubosmina longispina

50

Ostracoda - unidentified

Copepoda

Calanoida

Calanus glacialis

Calanus hyperboreus

Microcalanus pygmaeus

Pseudocalanus spp.

Derjuginia tolli

Eurytemora richingsi

Metridia lucens

Limnocalanus macrurus

Acartia longiremis

Unidentified nauplii

$\begin{array}{rr}17502 & 234086 \\ 708585 & 166810\end{array}$

$\begin{array}{ll}708585 & 166810\end{array}$

$2425217 \quad 1833068$

329463

2058

$7714 \quad 8563$

$1029 \quad 9206$

$39095 \quad 74176$

16461

1029

1029

1594

6017

2623

9257

Cyclopoida

Oithona similis

Cyclopina gracilis

Cyclopina sp. A

Cyclopina sp. B

Cyclopinodes sp.

Oncaea borealis

Harpacticoida

Pseudobradya minor

Harpacticus superflexus

Tisbe furcata

Mysidaceae

Mysis litoralis

Mysis oculata

1594

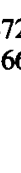

Mysis relicta

Isopoda

Epicaridea - unidentified
50

201

453

72

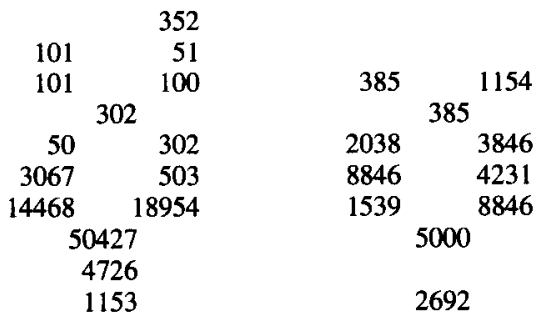

$50 \quad 302$

50

100

352

201

50

8087

$1539 \quad 385$

39231

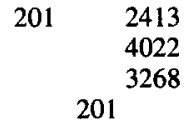

$3846 \quad 21923$

19231

4231

4615

$769 \quad 3462$

1539

1153

$201 \quad 251$

${ }_{385}^{26923}{ }^{27308} 769$

101

(continued) 
TABLE 1 (concluded)

\begin{tabular}{|c|c|c|c|}
\hline & $\begin{array}{c}\text { Nov } \\
(n=20)\end{array}$ & $\begin{array}{c}\text { Mar } \\
(n=9)\end{array}$ & $\underset{(n=1)}{\text { May }}$ \\
\hline Taxon & $8 \quad \%$ & $8 \quad 9$ & $8 \quad 9$ \\
\hline $\begin{array}{l}\text { Amphipoda } \\
\text { Hyperiidea } \\
\text { Hyperiidae } \\
\text { Parathemisto libellula }\end{array}$ & 21 & & \\
\hline $\begin{array}{l}\text { Gammaridea } \\
\text { Atylidae } \\
\text { Atylus carinatus }\end{array}$ & 111 & & \\
\hline $\begin{array}{l}\text { Gammaridae } \\
\text { Weyprechtia pinguis }\end{array}$ & 23 & & \\
\hline $\begin{array}{l}\text { Lysianassidae } \\
\text { Anonyx nugax } \\
\text { Acanthostepheia behringiensis } \\
\text { Boeckosimus plautus } \\
\text { Onisimus litoralis } \\
\text { Orchomenella pinguis }\end{array}$ & $\begin{array}{r}148 \\
21 \\
455 \\
337 \\
158\end{array}$ & & \\
\hline $\begin{array}{l}\text { Cirripedia } \\
\text { Balanus - unidentified nauplii } \\
\text { Unidentified parasitic larvae }\end{array}$ & & $\begin{array}{r}201 \\
50\end{array}$ & \\
\hline $\begin{array}{l}\text { Chaetognatha } \\
\text { Sagitta elegans }\end{array}$ & 158 & 101 & \\
\hline
\end{tabular}

*For animals not sexed, abundance is centered beneath month.

Among the cyclopoid copepods, Oithona similis was the most abundant, especially in May. Other cyclopoids, including Cyclopina gracilis, two unidentified Cyclopina species, Cyclopinodes sp., and Oncaea borealis, were also usually most common in May. Only female $O$. similis appeared in relatively large numbers. The harpacticoids $P$ seudobradya minor, Harpacticus superflexus, and Tisbe furcata, were present only in May and only juveniles were relatively common.

Other invertebrates constituted $<1 \%$ of the population in November and March and were not present in May. These included hydrozoans, ctenophores, unidentified polychaete larvae, mysids, amphipods, barnacle larvae, and chaetognaths (Table 1).

In the spring off Narwhal Island, Pseudocalanus spp. were also the most abundant organisms, constituting $83 \%$ of the population in April, $87 \%$ in May, and $45 \%$ in June. Mostly adults were present, but juvenile stages were also present in May and June. Acartia longiremis and Eurytemora herdmani adults were also common. A few cyclopoids were present, especially in June, and the harpacticoids Harpacticus superflexus and Helectinosoma neglectum became abundant in June (Table 2, Fig. 2).

Other invertebrates were present during the spring and generally made up $<12 \%$ of the total population. Hydrozoans, including meroplanktonic species Euphysa flammea and Halitholus cirratus and the holoplanktonic species Aeginopsis laurentii, were present in small numbers throughout the spring. Polychaete larvae were always present, as well as large numbers of unidentified echinoderm plutei, indicating reproduction of these benthic groups. Unidentified crustacean eggs were present in April and May.

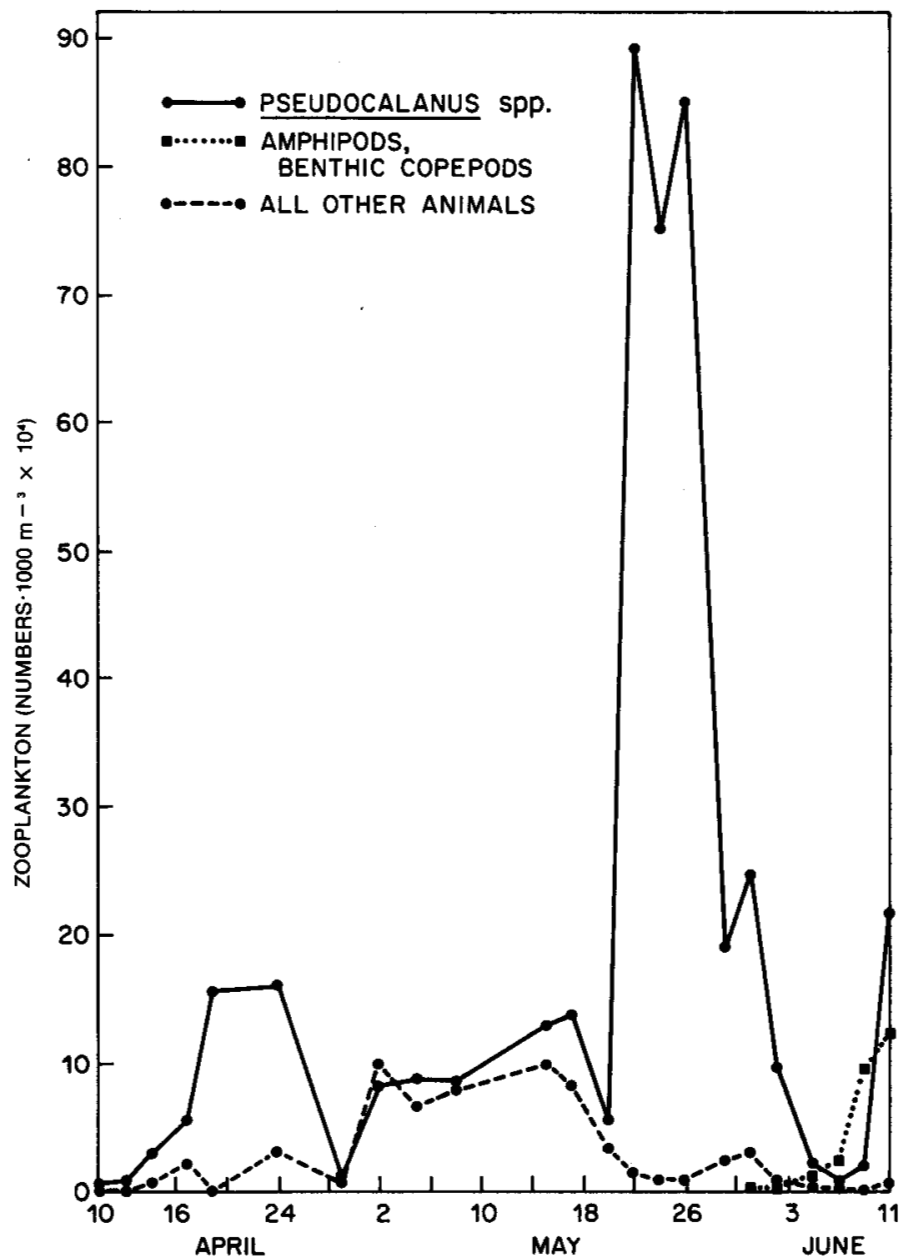

FIG. 2. Abundance of zooplankton groups off Narwhal Island, April-June 1980. 
TABLE 2. Mean abundance (individuals $\cdot 1000 \mathrm{~m}^{-3}$ ) of zooplankton at Narwhal Island, April-June 1980; all tows were horizontal

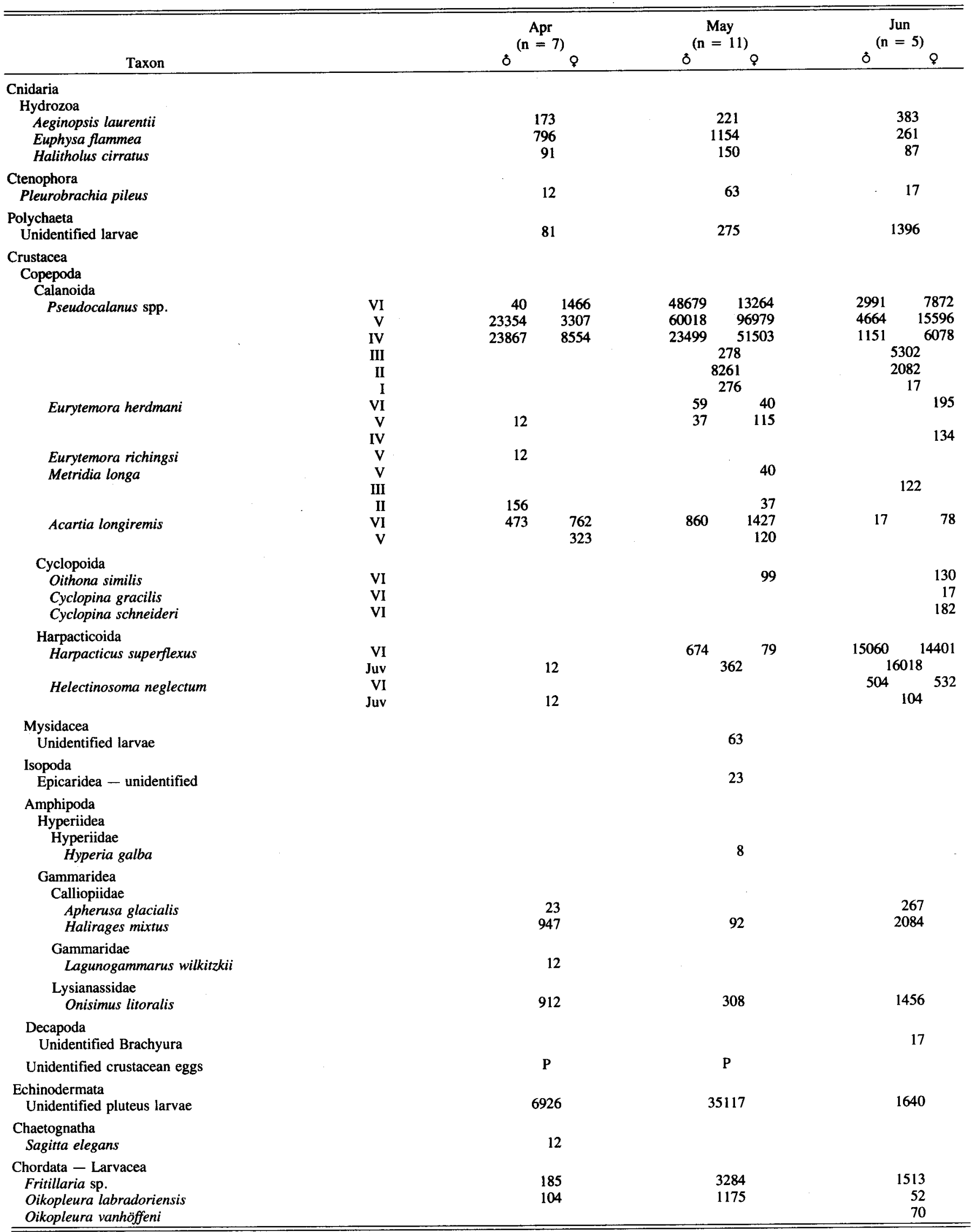


The amphipods Onisimus litoralis and Halirages mixtus were common throughout the spring, while Lagunogammarus wilkitzkii, Apherusa glacialis, and Hyperia galba were occasionally present. The larvaceans Fritillaria sp. and Oikopleura labradoriensis were also common.

\section{Correlation matrix}

The correlation matrix distinguished groups of species whose abundance tended to vary together. Table 3 shows two such groupings. Group one, consisting of Pseudocalanus spp., showed high correlation within the genus but not with any other taxon. A second group consisted of polychaetes, benthic copepods, and the amphipod Halirages mixtus. Stage III Pseudocalanus spp. correlated strongly with the benthic copepods of group two but not with other stages of Pseudocalanus. Considering the uncertainty of the taxonomy of this genus, this suggests the presence of more than one species. These two groups do not contain all 35 members of the correlation matrix, but the remaining 18 common species varied independently of any other species and were lumped together into a third group.

Figure 2 shows abundance versus time for all three groups of zooplankton. Large fluctuations in abundance were observed for Pseudocalanus spp. during the sampling period. Group two, benthic copepods and amphipods, were absent or present in low numbers in our samples until the early part of June, when their numbers increased greatly. The animals that did not correlate with any of the species in our collection are plotted as a third group. Their abundance was more uniform over the sampling period but declined as the ice melted in June.

TABLE 3. Average correlation coefficients of zooplankton groups

\begin{tabular}{|c|c|c|c|}
\hline Taxon & Stage & Sex & $\begin{array}{c}\text { Average } \\
\text { Correlation } \\
\text { Coefficient* }\end{array}$ \\
\hline \multicolumn{4}{|l|}{ Group 1} \\
\hline \multirow{9}{*}{ Pseudocalanus spp. } & VI & 0 & .65 \\
\hline & VI & \% & .49 \\
\hline & $\mathrm{V}$ & $\delta$ & .71 \\
\hline & V & q & .69 \\
\hline & IV & $\delta$ & .37 \\
\hline & IV & 9 & .75 \\
\hline & III & Juv & -.01 \\
\hline & II & Juv & .66 \\
\hline & I & Juv & .43 \\
\hline \multicolumn{4}{|l|}{ Group 2} \\
\hline Polychaeta & & & .47 \\
\hline Halirages mixtus & & & .34 \\
\hline \multirow[t]{3}{*}{ Harpacticus superflexus } & VI & $\delta$ & .62 \\
\hline & VI & q & .63 \\
\hline & & Juv & .60 \\
\hline \multirow[t]{3}{*}{ Helectinosoma neglectum } & VI & $\delta$ & .50 \\
\hline & VI & 웅 & .49 \\
\hline & & Juv & .31 \\
\hline Cyclopina spp. & VI & & .64 \\
\hline
\end{tabular}

*Average correlation coefficients are calculated as the sum of the correlation coefficients of a species with all the other members of a group divided by the number of group members.

\section{DISCUSSION}

Calanoid copepods were the dominant organisms in our samples, Pseudocalanus spp. being the most abundant genus. Adult animals were more numerous during winter, with juveniles generally occurring in early spring, although some juvenile stages were also present in November. It has been suggested (Cairns, 1967) that Pseudocalanus may take two years to reach maturity. This genus is widespread in the temperate zone and at high latitudes, being abundant from the North Pacific to the North Atlantic. In temperate areas it is usually found below $50 \mathrm{~m}$, but in higher latitudes it is found in cold surface waters and is more common nearshore, where it can be an important food source for fish (Brodskii, 1950). Although members of the genus Pseudocalanus were the most abundant organisms in our samples, they were not identified to species because of current confusion over the taxonomy of this genus (Buchanan and Sekerak, 1982; B. Frost and G. Heron, pers. comm.). Instead, we have grouped all members of this genus together as Pseudocalanus spp. until the taxonomic question is settled.

Calanus glacialis and C. hyperboreus were rarely found in our samples, although both are considered to be common in the Beaufort Sea (Shih and Laubitz, 1978). The breeding cycle of $C$. glacialis is generally not synchronized with environmental factors, and development to maturity is thought to take several years (Cairns, 1967), while C. hyperboreus is reported to be an opportunistic breeder, also with slow development.

Microcalanus pygmaeus lives in cold, deeper water (Brodskii, 1950), coming to the surface in winter (Digby, 1954). The spawning period is prolonged, with a new generation appearing in July (Cairns, 1967). Development takes place through the winter. Our data agree with these earlier observations from the eastern Arctic; in our samples, stage III, IV, and $V$ individuals were found in the shallow water of Stefansson Sound from mid-November through May.

Derjuginia tolli adults, abundant in November, were not found in spring, although we have found stages II, IV, V, and VI farther offshore in August-September (Horner, 1981). This is a neritic species usually found in shallow waters of the Arctic Basin (Grainger, 1965; Shih and Laubitz, 1978).

Two Eurytemora species were present in our samples. $E$. herdmani is considered to be a littoral species found in less saline water in the Bering Sea and along the Alaskan north coast (Brodskii, 1950). Johnson (1956) thought it might be an expatriate from the Bering Sea, and Redburn (1973) found it at Barrow only when the surface water temperature was $>7^{\circ} \mathrm{C}$. $E$. richingsi was originally described from $>500 \mathrm{~m}$ in the central Arctic Ocean (Heron and Damkaer, 1976), but it has also been reported from shallow water in the Beaufort Sea (English and Horner, 1977).

Acartia longiremis is a circumpolar arctic species that is mostly neritic but also occurs in surface water offshore. It is reported almost exclusively from surface waters of arctic marginal seas and is often found near melting ice (Johnson, 1956). In our samples, adults were found in November, March, April, May, and June but were most abundant in November. Grainger (1959) thought there was a suggestion of 
summer production of young with progressive development during winter. We found only adult stages in our samples.

Limnocalanus macrurus, rarely found as adults in November and May in Stefansson Sound, is primarily a freshwater species sometimes occurring in surface waters of $<2 \%$ salinity (Grainger, 1962). Shih and Laubitz (1978) reported it as sometimes numerous in the eastern Beaufort Sea.

The most common cyclopoid copepod in our samples was Oithona similis. Adults were present during all sampling times, with stages III and IV present in March. This species is circumpolar in distribution (Grainger, 1959). Adult males and females of another cyclopoid, Oncaea borealis, were present in March. Grainger (1959) found only adults at Igloolik in the Canadian Arctic and thought development either took place elsewhere or in deeper water. Small numbers of other cyclopoids were present in May 1979 and June 1980. The May 1979 tow was a vertical one with the net lowered to the bottom in Stefansson Sound, where attached macroalgae were present. These species, Cyclopina gracilis, Cyclopina sp. A, C. sp. B, and Cyclopinodes sp., are reported to be found close to shore among algae (Sars, 1913); that may account for their occurrence in this sample, but Cyclopina gracilis and $C$. schneideri were also found in horizontal tows taken in June off Narwhal Island, where there were no benthic macroalgae.

The harpacticoid copepods Pseudobradya minor and Harpacticus superflexus were also found in the vertical net haul in Stefansson Sound in June, while $H$. superflexus and Helectinosoma neglectus were present in April, May, and June off Narwhal Island. Montagna and Carey (1978) reported $H$. superflexus to have a wide distribution in the Beaufort Sea, occurring from $5-2000 \mathrm{~m}$. They found no males in their samples, collected farther offshore than ours. We found a few males in May at both the Stefansson Sound and Narwhal Island sites.

Hydrozoans became abundant in spring off Narwhal Island but were not abundant in Stefansson Sound, although Halitholus cirratus and Sarsia tubulosa were present in March.

Amphipods and mysids were also important components of the nearshore ecosystem, but they were relatively sparse in our samples, probably because of our sampling methods. Of these, Lagunogammarus wilkitzkii is an arctic species whose distribution is almost limited by the extent of the ice. It is found associated with the undersurface of the ice rather than being strictly pelagic, although it is planktonic in areas where ice is sparse in summer (Dunbar, 1964). It apparently feeds on the ice algae and other organic matter found on the undersurface of the ice. L. wilkitzkii is frequently found in the stomachs of ringed seals (Phoca hispida) (Dunbar, 1964).

Apherusa glacialis is an arctic, circumpolar, pelagic species that lives mainly near the surface (Stephensen, 1944) and is also often found associated with the underside of the ice (MacGinitie, 1955): Polar cod (Boreogadus saida) may selectively feed on this species (Barnard, 1959), and it has also been found in seal stomachs (MacGinitie, 1955). Both of these amphipod species successfully breed in the arctic (Tencati, 1970).

Onisimus litoralis is an abundant, shallow water species usually occurring in brackish water (Dunbar, 1954). Anonyx nugax, a circumpolar arctic-subarctic species, is confined to shallow water on the shelf and its distribution extends into the North Sea and the Skagerak. It may be used as a food species by ducks, cod, and bearded seals (Dunbar, 1954).

Mysids were not common in our samples, probably because most of our samples were collected above the bottom.

Larvaceans were present in most samples collected off Narwhal Island but not in Stefansson Sound. The species Fritillaria sp., Oikopleura labradoriensis, and $O$. vanhöffeni all occur widely in the arctic (Grainger, 1965) and are found at depths from 0-900 m (Leung, 1972).

Meroplanktonic larvae of polychaetes and barnacles were rarely found in Stefansson Sound, but polychaete larvae were common off Narwhal Island. Meroplankton production is apparently greater in the Chukchi and western Beaufort seas than in the eastern Beaufort Sea, perhaps because of the larger area of shallow water in the western areas (Johnson, 1956). Johnson (1956) found maximum abundance of barnacle larvae west of Point Barrow and considered that a sizeable portion of the barnacle larvae found in the western Beaufort Sea may be due to advection. Our samples were collected close to shore, possibly in an area not greatly influenced by water from the west. Also in our sampling area there is little solid substrate for adult barnacles, while polychaetes are a common constituent of the benthic community both inshore and offshore (Broad, 1978; Carey et al., 1974). Large numbers of unidentified echinoderm pluteus larvae were abundant off Narwhal Island, and echinoderms, especially ophiuroids, are also conspicuous members of the benthic community (Carey and Ruff, 1977).

The numbers of the three groups identified by the correla-

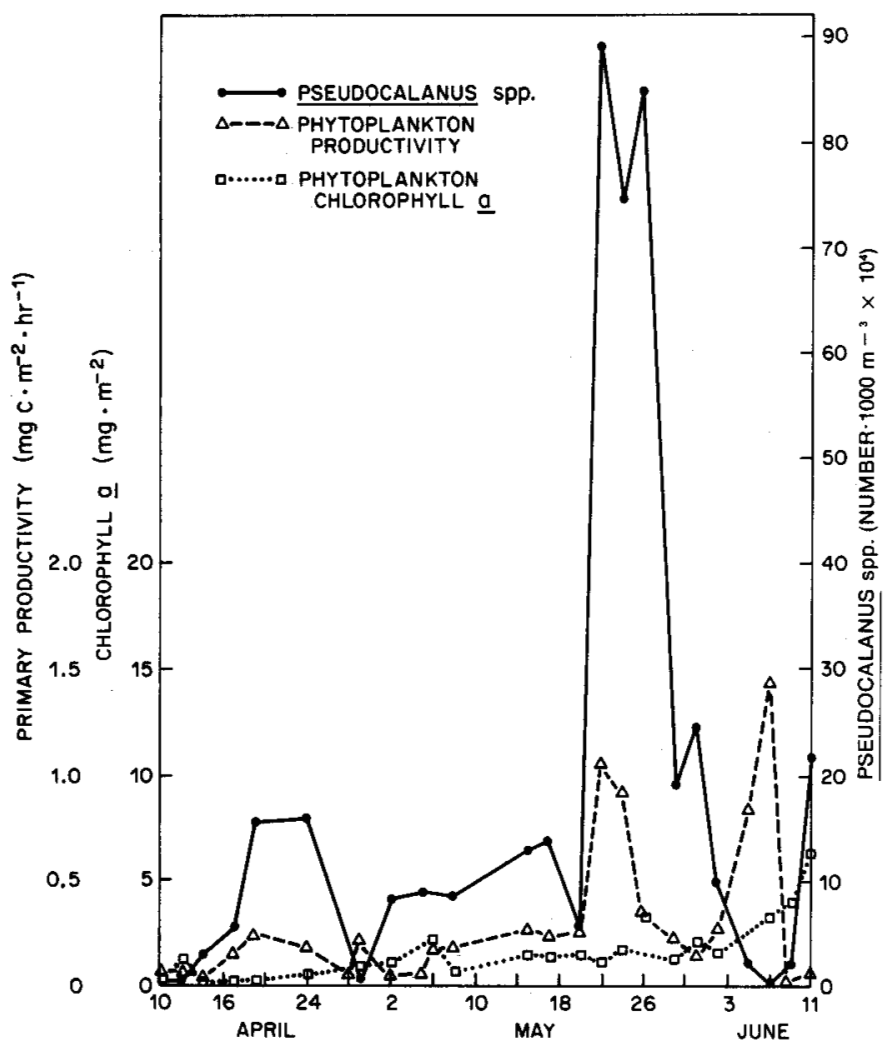

FIG. 3. Comparison of Pseudocalanus spp. abundance with primary productivity and chlorophyll $a$ concentration off Narwhal Island, April-June 1980. 
tion matrix varied during the spring. The movement of large swarms of Pseudocalanus spp. past our study site, as indicated in Figure 2, may have been due to the local current regime and could explain why we did not see any clear progression of life cycle stages during our study. Comparison of group-one abundance with chlorophyll $a$ concentrations and primary productivity (Fig. 3) also shows no clear relationship, but an increase in both chlorophyll $a$ and productivity (Horner and Schrader, 1982) after a particularly large swarm of Pseudocalanus spp. late in May suggests there is some grazing pressure.

The increase in amphipods, polychaetes, and benthic copepods coincided with the disappearance of the ice algae as the ice melted in June. These animals had apparently been living in the ice and utilizing the ice algal community as a concentrated source of food. Polychaetes and amphipods were present in our samples throughout the spring, however, and were thus not found exclusively within the bottom ice community.

Species composition and abundance of zooplankton in arctic Alaskan coastal waters change substantially with the onset of spring. Winter populations, primarily composed of a few species of calanoid copepods, give way to a more diverse community that includes additional copepod genera, hydrozoans, amphipods, larvaceans, and larval stages of planktonic and benthic invertebrates during spring. Data from the Prudhoe Bay area indicate that this more diverse community continues through the summer (Horner et al., 1974). With the onset of winter, zooplankton populations decline in both abundance and diversity.

\section{ACKNOWLEDGEMENTS}

Winter sampling in November 1978 and March 1979 was done by $T$. Kaperak, who also analyzed the non-copepod portion of the winter samples; May 1979 sampling was done by K. Daly; spring 1980 sampling was done by D. Murphy and G.C. Schrader; K. Persons, S. Petersen, and NOAA helicopter crews provided logistic support in the field; G. Heron identified the copepod portion of all the samples. This study was supported by the Bureau of Land Management through interagency agreement with the National Oceanic and Atmospheric Administration as part of the Outer Continental Shelf Environmental Assessment Program. Computer time for the correlation analysis was provided by the Department of Oceanography, Texas A \& M University.

\section{REFERENCES}

BARNARD, J.L. 1959. Epipelagic and under ice Amphipoda of the Central Arctic Basin. In: Bushnell, V., ed. Scientific Studies at Fletcher's Ice Island, T-3, 1952-1955. Geophysical Research Papers 63:115-152.

BIGELOW, H. 1920. Medusae and ctenophores from the Canadian Arctic Expedition. Report of the Canadian Arctic Expedition 8(H): 1-22.

BROAD, A.C. 1978. Reconnaissance characterization of littoral biota, Beaufort and Chukchi seas. Environmental Assessment of the Alaskan Continental Shelf, Annual Reports 5:1-84.

BENEDICT, A., DUNTON, K., KOCH, H., MASON, D.T., SCHNEIDER, D.E., and SCHONBERG, S.V. 1979. Environmental assessment of selected habitats in the Beaufort and Chukchi littoral system. Environmental Assessment of the Alaskan Continental Shelf, Annual Reports $3: 361-542$.

BRODSKII, K.A. 1950. Calanoida of the Far Eastern Seas and Polar Basin of the USSR. Zoological Institute, Akademy Nauk SSSR. Translated from Russian by Israel Program for Scientific Transiation, Jerusalem, 1967. $440 \mathrm{p}$.
BUCHANAN, R.A., and SEKERAK, A.D. 1982. Vertical distribution of zooplankton in eastern Lancaster Sound and western Baffin Bay, July-October 1978. Arctic 35:41-55.

CAIRNS, A.A. 1967. The zooplankton of Tanquary Fjord, Ellesmere Island, with special reference to calanoid Copepoda. Journal of the Fisheries Research Board of Canada 24:555-568.

CAREY, A.G., Jr., and RUFF, R.E. 1977. Ecological studies of the benthos in the western Beaufort Sea with special reference to bivalve molluscs. In: Dunbar, M.J., ed. Polar Oceans. Calgary, Alberta: The Arctic Institute of North America. 505-530.

CASTILLO, J.G., and DICKINSON, J.J. 1974. Benthic ecology of the western Beaufort Sea continental margin: preliminary results. In: Reed, J.C., and Sater, J.E., eds. Arlington, Virginia: The Arctic Institute of North America. 665-680.

CRANE, J.J., and COONEY, R.T, 1974. The nearshore benthos. In: Alexander, V., et al., eds. Environmental Studies of an Arctic Alaskan Estuarine System. Report R74-1. Institute of Marine Science, University of Alaska, Fairbanks, Alaska. 411-466.

DIGBY, P.S.B. 1954. The biology of the marine planktonic copepods of Scoresby Sound, East Greenland. Journal of Animal Ecology 23:298-338.

DUNBAR, M.J. 1954. The amphipod Crustacea of Ungava Bay, Canadian Eastern Arctic. Journal of the Fisheries Research Board of Canada 11: 709-798.

1964. Euphausids and pelagic amphipods. Distribution in North Atlantic and Arctic waters. Serial Atlas of the Marine Environmental Folio 6. American Geographical Society, New York. 2 p. +8 p1.

ENGLISH, T.S., and HORNER, R. 1976. Beaufort Sea plankton studies. Environmental Assessment of the Alaskan Continental Shelf, Annual Reports 7:593-671.

1977. Beaufort Sea plankton studies. Environmental Assessment of the Alaskan Continental Shelf, Annual Reports 9:275-627.

GRAINGER, E.H. 1959. The annual oceanographic cycle at Igloolik in the Canadian Arctic. I. The zooplankton and physical and chemical observations. Journal of the Fisheries Research Board of Canada 16:453-501.

1962. Zooplankton of Foxe Basin in the Canadian Arctic. Journal of the Fisheries Research Board of Canada 19:377-400.

1965. Zooplankton from the Arctic Ocean and adjacent Canadian water. Journal of the Fisheries Research Board of Canada 22:543-564.

GRIFFITHS, W.B., and DILLINGER, R.E. 1981. Invertebrates. Environmental Assessment of the Alaskan Continental Shelf, Final Reports 8:vi-198.

HERON, G.A., and DAMKAER, D.M. 1976. Eurytemora richingsi, a new species of deep-water calanoid copepod from the Arctic Ocean. Proceedings of the Biological Society of Washington 89:127-136.

HORNER, R. 1978. Beaufort Sea plankton studies. Environmental Assessment of the Alaskan Continental Shelf, Annual Reports 5:85-142.

1979. Beaufort Sea plankton studies. Environmental Assessment of the Alaskan Continental Shelf, Annual Reports 3:543-639.

1981. Beaufort Sea plankton studies. Environmental Assessment of the Alaskan Continental Shelf, Final Reports 13:65-314.

COYLE, K.O., and REDBURN, D.R. 1974. Ecology of the plankton of Prudhoe Bay, Alaska. Report R74-2. Institute of Marine Science, University of Alaska, Fairbanks, Alaska. 99 p.

HORNER, R., and SCHRADER, G.C. 1982. Relative contributions of ice algae, phytoplankton, and benthic microalgae to primary production in nearshore regions of the Beaufort Sea. Arctic 35:485-503.

JOHNSON, M.W. 1956. The plankton of the Beaufort and Chukchi Sea areas of the Arctic and its relation to the hydrography. Technical Paper No. 1. Washington, D.C.: The Arctic Institute of North America. $32 \mathrm{p}$.

1958. Observations on inshore zooplankton collected during summer 1957 at Point Barrow, Alaska. Journal of Marine Research 17:272-281.

LEUNG, Y.M. 1972. Appendicularians of the Central Arctic. In: Kobayashi, H., ed. Taxonomic Guides to Arctic Zooplankton (VI). Technical Report 2. Department of Biological Sciences, University of Southern California, Los Angeles, California: 3-12.

MacGINITIE, G.E. 1955. Distribution and ecology of the marine invertebrates of Point Barrow, Alaska. Smithsonian Miscellaneous Collections 128(9):1-201.

McEWEN, G.F., JOHNSON, M.W., and FOLSOM, T.R. 1954. A statistical analysis of the performance of the Folsom plankton splitter based upon test 
observations. Archiv für Meteorologie, Geophysik und Bioklimatologie, series A, 7:507-527.

MONTAGNA, P.A., and CAREY, A.G., Jr. 1978. Distributional notes on Harpacticoida (Crustacea: Copepoda) collected from the Beaufort Sea (Arctic Ocean). Astarte 11:117-122.

MURDOCH, J. 1885. Marine invertebrates (exclusive of mollusks). In: Ray, P.H., ed. Report of the International Expedition to Point Barrow, Alaska. Washington, D.C.: U.S. Government Printing Office. 136-176.

REDBURN, D.R. 1973. The ecology of the inshore marine zooplankton of the Chukchi Sea near Point Barrow, Alaska. Unpub. M.S. thesis, Institute of Marine Science, University of Alaska, Fairbanks, Alaska. 172 p.

SARS, G.O. 1913. An Account of the Crustacea of Norway VI. Copepoda Cyclopoida pts. I \& II. Oithonidae, Cyclodinidae, Cyclopidae (part). The Bergen Museum. Christiania: Alb. Cammarmyer's Forlag. 225 p.

SAS INSTITUTE INC. 1982. SAS User's Guide:Basics. Cary, North Carolina: Statistical Analysis Systems Inc. 923 p.
SCHMITT, W. 1919. The schizopod crustaceans of the Canadian Arctic Expedition, 1913-1918. Report of the Canadian Arctic Expedition VII(B): $1-9$.

SHIH, C.-T., and LAUBITZ, D.R. 1978. Zooplankton distribution in the eastern Beaufort Sea and Northwest Passage. Astarte 11:45-54.

SHOEMAKER, C. 1920. The amphipod crustaceans of the Canadian Arctic Expedition. Report of the Canadian Arctic Expedition VII(E):1-30.

STEPHENSEN, K. 1944. The zoology of East Greenland. Amphipoda. Meddelelser om Grónland 121(14):1-165.

TENCATI, J.R. 1970. Amphipods of the Central Arctic. In: Leung, Y.M., and Kobayashi, H., eds. Taxonomic Guides to Arctic Zooplankton. Technical Report 2. Department of Biological Sciences, University of Southern California, Los Angeles, California. 3-37.

WILLEY, A. 1920. Report on the marine Copepoda collected during the Canadian Arctic Expedition. Report of the Canadian Arctic Expedition VII(K): $1-46$. 